\title{
SIKAP REMAJA PUTRI DALAM MENGHADAPI PERUBAHAN FISIK MASA PUBERTAS
}

\author{
Bella Kartini Rochmania \\ Departemen Promosi Kesehatan dan Ilmu Perilaku Fakultas Kesehatan Masyarakat \\ Email: bella.kartini@gmail.com
}

\begin{abstract}
Physical changes in teenager is a principal characteristic from biologic process in puberty age. Wrong attitude in confront of physical changes can make girl dislike moreover hate the physical changes that she's got, so the parent have an important role to girl's attitude. The objective of this research is to analyze the correlation of girls perception about parenting education type with the attitude of teenager facing physical changes in puberty age in Student of $7^{\text {th }}$ class of Junior High School 13 Malang City. This research is using observational with cross sectional. Number of population 120 students, number of sample 92 students, with simple random sampling technique. Data collecting applies questioner sheet filled out by the respondent. Data is showing table type and text. The result of research is using chisquare showing that majority of respondent are democratic type about 59 students $(64,1 \%)$. Majority of respondent $(64,1 \%)$ have negative attitude (unfavorable) in confront of physical changes, and the girls that have perception democratic type have negative attitude (unfavorable) in confront of physical changes. Then, be obtain value $x^{2}$ table (5,991), and the conclusion that there is no Corelation between perception about Parenting Education Type with Attitude Facing Physical Changes in Puberty Age.
\end{abstract}

Keyword: girls, parenting education type, physical change

\begin{abstract}
Abstrak: Perubahan fisik merupakan ciri utama dari proses biologis yang terjadi pada masa puber. Sikap yang salah dalam menghadapi perubahan fisik yang terjadi dapat membuat remaja putri cenderung tidak menyukai bahkan membenci perubahan fisik yang dialami. Oleh karena itu orang tua berperan penting dalam membentuk sikap remaja. Tujuan penelitian ini menganalisis hubungan persepsi remaja putri tentang tipe pola asuh orang tua dengan sikap menghadapi perubahan fisik masa pubertas. Penelitian menggunakan observasional dengan pendekatan cross sectional. Populasi penelitian adalah siswi kelas VII di SMPN 13 Kota Malang sebanyak 120 siswi, sampel sejumlah 92 siswi. Pengambilan sampel menggunakan simple random sampling. Pengumpulan data menggunakan instrumen berupa kuesioner yang diisi sendiri oleh responden. Data disajikan dalam bentuk tabel dan tekstual. Analisis data menggunakan Chi-Square. Hasil penelitian menunjukkan bahwa mayoritas responden mempersepsikan tipe pola asuh orang tuanya demokratis yaitu sejumlah 59 siswi $(64,1 \%)$. Mayoritas responden $(64,1 \%)$ bersikap negatif (unfaforable) dalam menghadapi perubahan fisik masa pubertas, dan siswi yang mempersepsikan tipe pola asuh orang tuanya demokratis lebih banyak bersikap negative dalam menghadapi perubahan fisik masa pubertas. Kemudian didapatkan nilai $\mathrm{x}^{2}$ hitung 3,895 lebih kecil dari $\mathrm{x}^{2}$ tabel $(5,991)$ sehingga dapat disimpulkan bahwa tidak ada hubungan antara persepsi pola asuh orang tua dengan sikap menghadapi perubahan fisik masa pubertas.
\end{abstract}

Kata kunci: remaja putri, tipe pola asuh, perubahan fisik

\section{PENDAHULUAN}

Perubahan fisik remaja merupakan ciri utama dari proses biologis yang terjadi pada masa pubertas. Pada masa ini terjadi perubahan fisik secara cepat, yang tidak seimbang dengan perubahan kejiwaan (mental emosional). Perubahan fisik yang terjadi termasuk pertumbuhan organ-organ reproduksi untuk mencapai kematangan agar mampu melangsungkan fungsi reproduksi. Perubahan yang cukup besar ini dapat membingungkan remaja yang mengalaminya. Remaja sangat penting untuk mempelajari perubahan yang terjadi setiap tahap kehidupannya. Remaja dapat belajar menerima kondisi fisik diri serta merawat dan menjaganya.

Masa remaja merupakan sebuah transisi dari masa anak-anak dengan masa dewasa. Remaja pada masa ini masih labil dan tidak memiliki pegangan hidup yang pasti. Remaja cenderung berbuat sesuai dengan pikiran dan nalarnya sendiri. Hal tersebut merupakan cara remaja untuk mencari 
jati dirinya. Rasa ingin tahu yang tinggi, ingin mencoba hal baru membuat remaja tidak jarang menjadi terjerumus dalam permasalahan. Permasalahan yang sering terjadi seperti anti sosial dan pergaulan bebas. Anti sosial membuat remaja kurang terbuka terhadap lingkungannya yang dapat menjadi salah penerimaan pada informasi yang diperoleh.

Informasi yang holistik terutama dalam menghadapi perubahan fisik masa pubertas dapat dipupuk dari unit kelompok terkecil yaitu keluarga. Pada dasarnya remaja lebih terkesan akan nilai-nilai luhur yang berasal dari keteladanan orang tua mereka dari pada mendapatkan nasihat yang hanya melalui ucapan saja. Orang tua dalam hal ini berperan penting dalam membentuk pribadi remaja dan cara untuk mengantarkan pada proses pendewasaan terutama pengenalan terhadap perubahan fisik yang dialami masa pubertas.

Penelitian yang dilakukan oleh Siti Inayah Rohmaniah tahun 2014 tentang "Gambaran Pengetahuan dan Sikap Remaja Putri dalam Menghadapi Perubahan Fisik Saat Pubertas di Pondok Pesantren Al-Baqiyatussholihat" menunjukkan bahwa remaja putri dalam menghadapi perubahan fisik pubertas bersikap negatif yaitu sebanyak 53,3\% dari total responden. Hal tersebut menjelaskan bahwa sebagian besar remaja putri belum dapat menerima perubahan fisik yang terjadi pada masa pubertas. Data yang diperoleh dari penelitian tersebut menjelaskan bahwa rasa takut, malu, cemas, dan mudah marah saat menstruasi dirasakan oleh remaja putri. Sikap dipengaruhi oleh orang yang dianggap penting. Pada penelitian orang yang dianggap penting dapat membuat remaja berfikiran searah dengan yang dihadapinya sehingga remaja putri menganggap orang tua merupakan salah satu orang yang dianggap penting.

Pola asuh orang tua banyak mempengaruhi sikap remaja sebagai orang yang dianggap penting dalam hidupnya, sehingga mempengaruhi sikap remaja dalam mempersiapkan dirinya menuju masa pubertas, mengenali ciri fisik, maupun perubahan masa pubertas yang akan memunculkan sikap positif maupun sikap negatif pada remaja. Sikap tersebut yang akan membentuk karakter diri remaja saat berada di lingkungan sekitarnya.

Remaja dan orang tua memiliki adanya keterkaitan yang dapat dibentuk dari adanya interaksi dan perilaku yang dimiliki oleh keduanya. Peneliti mengidentifikasi pesepsi pola asuh orang tua. Berdasarkan literatur yang didapat peneliti ingin mengidentifikasi sikap remaja putri terhadap perubahan fisik yang dialami saat pubertas. Penelitian ini juga mengidentifikasi adanya hubungan persepsi remaja putri tentang pola asuh orang tua dengan sikap menghadapi perubahan fisik masa pubertas.

\section{METODE}

Desain penelitian yang digunakan dalam penelitian ini adalah observasional dengan pendekatan cross sectional. Populasi penelitian adalah seluruh siswi kelas VII di SMP Negeri 13 Kota Malang, yaitu sebanyak 120 orang yang telah memenuhi kriteria inklusi. Kriteria inklusi yang digunakan adalah siswi kelas VII yang berusia 12-15 tahun, bersedia menjadi responden, tinggal bersama orang tua sejak kecil, dan sudah menstruasi. Kriteria ekslusi yang digunakan ialah siswi yang tidak hadir saat penelitian dan siswi yang mempersepsikan lebih dari satu tipe pola asuh orang tuannya.

Penelitian menggunakan teknik simple random sampling untuk mengambil sampel sejumlah 92 orang. Instrumen yang digunakan dalam penelitian ini adalah kuesioner yang diisi sendiri oleh responden penelitian. Sebelum digunakan kuesioner dilakukan uji validitas dan reabilitas untuk mendapatkan hasil yang berkualitas dengan melalui.

Setelah didapatkan data, peneliti melakukan pengolahan data mulai dari editing, coding, scoring, transferring, dan tabulating yang selanjutnya dilakukan analisis menggunakan Chi-Square. Analisis data menggunakan Uji Chi-Square menghasilkan derajat kemaknaan 95\% (taraf signifikansi $=5 \%$ ). Ho diterima jika $x_{\text {hit }}^{2}<x_{\text {tabel }}^{2}, x_{\text {hit }}^{2}<x_{\text {tabel }}^{2}$, tidak ada hubungan, Ho ditolak jika $x_{\text {hit }}^{2}>x_{\text {tabel }}^{2}$ $x_{\text {hit }}^{2}>x_{\text {tabel }}^{2}$, ada hubungan. 


\section{HASIL PENELITIAN}

SMP Negeri 13 merupakan sekolah yang terletak di Jalan Sunan Ampel Nomor 11 Kota Malang dan berada dilingkungan sekitar pondok pesantren dan Universitas Islam Negeri Maulana Malik Ibrahim Malang. Siswa kelas VII dalam satu angkatan terdiri dari 324 orang yang terdiri dari 189 siswi dan 135 siswi. Penelitian yang telah dilakukan menghasilkan distribusi frekuensi umur siswi kelas VII SMP Negeri 13 Kota Malang yang menjadi responden penelitian.

Didapatkan presentase umur responden yang dominan. Umur responden merupakan salah satu karakteristik responden penelitian ini.

Berdasarkan tabel 1 dapat diketahui bahwa lebih dari setengah siswi kelas VII yang menjadi responden penelitian berumur 13 tahun yaitu sebanyak 70 orang $(76,1 \%)$, sedangkan responden yang berumur 12 tahun hanya berjumlah 9 orang $(9,8 \%)$. Seluruh siswi kelas VII SMP Negeri 13 Kota Malang yang menjadi responden penelitian telah mendapatkan informasi pertama tentang perubahan fisik yang dialami pada masa pubertas.

Informasi terkait perubahan fisik yang terjadi masa pubertas diberikan pertama kali oleh orang yang dianggap penting responden. Orang yang dianggap penting

Tabel 1. Distribusi Frekuensi Umur Responden.

\begin{tabular}{|c|c|c|c|}
\hline \multirow[t]{2}{*}{ Umur } & \multirow[t]{2}{*}{$\begin{array}{c}\text { Sumber } \\
\text { Informasi }\end{array}$} & \multicolumn{2}{|c|}{ Frekuens } \\
\hline & & $\mathbf{n}$ & $\%$ \\
\hline \multirow[t]{3}{*}{12} & Guru & 3 & \multirow{3}{*}{9,8} \\
\hline & Orang Tua & 5 & \\
\hline & Saudara & 1 & \\
\hline \multirow[t]{4}{*}{13} & Guru & 17 & \multirow{4}{*}{76,1} \\
\hline & Orang Tua & 47 & \\
\hline & Saudara & 1 & \\
\hline & Tenaga Kesehatan & 5 & \\
\hline \multirow[t]{4}{*}{14} & Guru & 4 & \multirow{3}{*}{14,1} \\
\hline & Orang Tua & 7 & \\
\hline & Saudara & 2 & \\
\hline & Total & 92 & 100 \\
\hline
\end{tabular}

Sumber: data primer 2014 dalam penelitian ini dijabarkan peneliti yaitu orang tua, guru, saudara, serta tenaga kesehatan. Pada tabel 2 distribusi frekuensi sumber informasi pertama responden tentang perubahan fisik masa pubertas di SMP Negeri 13 Kota Malang.

Tabel 1 juga menunjukkan bahwa responden penelitian telah mendapat informasi tentang perubahan fisik yang terjadi pada masa pubertasnya. Sumber informasi tersebut dapat diperoleh dari orang tua, guru, saudara dan bahkan dari tenaga kesehatan. Sumber informasi untuk pertama kalinya disampaikan oleh orang tua responden sendiri yaitu sebanyak 60 siswi $(65,2 \%)$. Sedangkan sedikitnya responden yang telah mendapat informasi tentang perubahan fisik pubertas dari saudara dan tenaga kesehatan yaitu masing-masing sebanyak 4 siswi yaitu hanya $4,4 \%$ dari keseluruhan responden penelitian.

Persepsi remaja putri tentang tipe pola asuh orang tua pada siswi kelas VII di SMP Negeri 13 Kota Malang dengan memberikan 15 pertanyaan kepada responden. Responden penelitian dapat memilih jawaban dari tiga pilihan jawaban pertanyaan yang berisikan persepsi pola asuh otoriter, permisif, dan demokratis.

Tabel 2 dapat diketahui bahwa lebih dari setengah siswi kelas VII menghadapi perubahan fisik yang terjadi pada masa pubertas dengan sikap negatif yaitu sebanyak 59 orang $(64,1 \%)$ dari keseluruhan responden penelitian, sedangkan sisanya bersikap positif terhadap perubahan fisik yang terjadi.

Pertanyaan favorable pada tabel 3 berisikan hal-hal positif mengenai sikap terhadap perubahan fisik masa pubertas. Tabel menunjukkan bahwa dari tujuh pertanyaan favorable kecenderungan

Tabel 2. Distribusi Frekuensi Responden Berdasarkan Sikap Menghadapi Perubahan Fisik Masa Pubertas.

\begin{tabular}{lcc}
\hline \multicolumn{1}{c}{ Sikap } & Frekuensi (f) & Presentase (\%) \\
\hline Positif & 33 & 35,9 \\
Negatif & 59 & 64,1 \\
\hline Jumlah & 92 & 100 \\
\hline
\end{tabular}

Sumber: data primer 2014. 
siswi menjawab sangat setuju dan setuju. Namun pada pertanyaan tentang kesenangan mencari informasi pendidikan seksual dan kesehatan reproduksi sebanyak 19 responden tidak setuju dan 23 responden sangat tidak setuju. Pernyataan membersihkan alat kelamin setelah BAK dengan air dan mengeringkannya sebanyak 28 responden tidak setuju dan 13 responden sangat tidak setuju. Pernyataan menerima pembesaran pinggul sebanyak 43 responden tidak setuju dan 20 responden sangat tidak setuju. Frekuensi jawaban pertanyaan favorable menunjukkan bahwa dengan banyaknya jawaban tidak setuju pada pilihan jawaban menunjukkan bahwa remaja putri memiliki sikap positif yang sedikit terhadap perubahan fisik yang sedang dialami pada masa pubertas. Pada tabel 3 mengenai pertanyaan unfavorable untuk responden dalam menghadapi perubahan fisik pubertas menunjukkan kecenderungan responden menjawab pernyataan dengan jawaban setuju dan sangat setuju dari pada pilihan jawaban tidak setuju maupun pilihan jawaban sangat tidak setuju. Pertanyaan unfavorable merupakan pernyataan sikap yang berisi hal-hal yang negatif mengenai sikap terhadap perubahan fisik masa pubertas.

Tabel 3. Distribusi Frekuensi Jawaban Sikap Favoreble dan Unfavorable Remaja Putri dalam Menghadapi Pubertas.

\begin{tabular}{|c|c|c|c|c|}
\hline Pertanyaan Faforable & SS & $\mathbf{S}$ & TS & STS \\
\hline $\begin{array}{l}\text { Menstruasi menunjukkan arti dapat melanjutkan keturunan } \\
\text { dan siap untuk menikah }\end{array}$ & 30 & 44 & 11 & 7 \\
\hline Seks bebas dapat berakibat buruk & 62 & 15 & 10 & 5 \\
\hline $\begin{array}{l}\text { Senang mencari informasi pendidikan seksual dan kesehatan } \\
\text { reproduksi }\end{array}$ & 7 & 13 & 49 & 23 \\
\hline $\begin{array}{l}\text { Setelah BAK membersihkan alat kelamin dengan air dan } \\
\text { mengeringkanya }\end{array}$ & 27 & 24 & 28 & 13 \\
\hline $\begin{array}{l}\text { Perubahan fisik dan biologis terjadi pada remaja putri yaitu } \\
\text { menstruasi }\end{array}$ & 41 & 34 & 16 & 1 \\
\hline Menerima pembesaran pinggul yang terjadi & 13 & 16 & 43 & 20 \\
\hline Aborsi memperburuk atau mengganggu kesehatan & 55 & 35 & 2 & 0 \\
\hline \multicolumn{5}{|l|}{ Pertanyaan Unfavorable } \\
\hline pendidikan seksual merupakan hal sensitif & 39 & 46 & 2 & 5 \\
\hline Takut gemuk dan mudah diet & 30 & 52 & 4 & 6 \\
\hline Senang menggunakan celana ketat & 29 & 43 & 19 & 1 \\
\hline Seksual bebas tidak dapat menyebabkan kehamilan & 37 & 49 & 2 & 4 \\
\hline Pembesaran payudara membuat saya malu & 39 & 48 & 4 & 1 \\
\hline Pendidikan seks untuk orang yang sudah menikah saja & 39 & 47 & 2 & 4 \\
\hline $\begin{array}{l}\text { Malu dengan tumbuhnya rambut pada ketiak dan sekitar } \\
\text { kelamin }\end{array}$ & 38 & 44 & 4 & 6 \\
\hline Seksual bebas tidak selamanya menimbulkan risiko PMS & 24 & 34 & 11 & 23 \\
\hline $\begin{array}{l}\text { Kesehatan reproduksi lebih baik diberikan kepada orang } \\
\text { dewasa }\end{array}$ & 29 & 48 & 3 & 12 \\
\hline
\end{tabular}

Sumber: data primer 2014.

Tabel 4. Distribusi Frekuensi Responden Berdasarkan Persepsi Remaja Putri Tentang Tipe Pola Asuh pada Siswi Kelas VII di SMP Negeri 13 Kota Malang.

\begin{tabular}{|c|c|c|}
\hline Persepsi Tipe Pola Asuh & Frekuensi (f) & Presentase $(\%)$ \\
\hline Otoriter & 14 & 15,2 \\
\hline Permisif & 19 & 20,7 \\
\hline Demokratis & 59 & 64,1 \\
\hline Jumlah & 92 & 100 \\
\hline
\end{tabular}

Sumber: data primer 2014 
Dari semua pernyataan unfavorable hampir semua menunjukkan sikap negatif terhadap perubahan fisik yang sedang dialami pada masa pubertas. Salah satu pernyataan unfavorable yaitu pendidikan seksual merupakan hal sensitif, menunjukkan banyaknya responden memilih jawaban sangat setuju sebanyak 39 responden dan jawaban setuju sebanyak 46 responden. Tabel 4 dapat diketahui bahwa lebih dari setengah responden mempersepsikan pola asuh orang tuanya demokratis yaitu sebanyak 59 orang $(64,1 \%)$. Sedangkan persepsi pola asuh orang tua yang sedikit adalah pola asuh otoriter sejumlah 14 siswi $(15,2 \%)$. Data tersebut menunjukkan total asuh demokratis banyak dipersepsikan responden sebagai tipe pola asuh orang tuanya.

Hasil perhitungan baik manual maupun komuterisasi diperoleh bahwa jumlah $\mathrm{x}^{2}$ hitung sebesar 3,895 sedangkan $\mathrm{x}^{2}$ tabel sebesar 5,991 sehingga $x^{2}$ hitung $<x^{2}$ tabel $(3,895<5,991)$ dengan demikian didapatkan Ho diterima.

Hubungan persepsi remaja putri tentang tipe pola asuh orang tua terhadap sikap menghadapi perubahan fisik pubertas berdasarkan tabel 5 diketahui bahwa 59 siswi yang mempersepsikan tipe pola asuh orang tuanya demokratis, sebanyak 42 orang $(71,2 \%)$ diantaranya bersikap negatif dalam menghadapi perubahan fisik masa pubertas. Hasil penelitian menunjukkan arti bahwa tidak ada hubungan persepsi remaja putri tentang tipe pola asuh orang tua dengan

Tabel 5. Tabulasi Silang Hubungan Persepsi Remaja Putri tentang Tipe Pola Asuh Orang Tua dengan Sikap Menghadapi Perubahan Fisik Masa Pubertas.

\begin{tabular}{|c|c|c|c|c|c|c|}
\hline \multirow{3}{*}{$\begin{array}{c}\text { Persepsi } \\
\text { Tipe Pola } \\
\text { Asuh } \\
\text { Orang Tua }\end{array}$} & \multicolumn{4}{|c|}{ Sikap } & \multirow{2}{*}{\multicolumn{2}{|c|}{ Jumlah }} \\
\hline & \multicolumn{2}{|c|}{ Positif } & \multicolumn{2}{|c|}{ Negatif } & & \\
\hline & $\mathbf{F}$ & $\%$ & $\mathbf{F}$ & $\%$ & f & $\%$ \\
\hline Otoriter & 6 & 42,9 & 8 & 57,1 & 14 & 100 \\
\hline Permisif & 10 & 52,6 & 9 & 47,4 & 19 & 100 \\
\hline Demokratif & 17 & 28,8 & 42 & 71,2 & 59 & 100 \\
\hline Jumlah & 33 & 35,9 & 59 & 64,1 & 92 & 100 \\
\hline
\end{tabular}

Sumber: data primer 2014. sikap menghadapi perubahan fisik masa pubertas pada siswi kelas VII di SMP Negeri 13 Kota Malang tahun 2014.

\section{PEMBAHASAN}

Persepsi muncul dari adanya stimulus yang menghasilkan penafsiran informasi, memberikan gambaran, dan pemahaman tentang lingkungan sehingga seseorang dapat memberikan penilaian dan anggapan tentang suatu hal tersebut. Contoh persepsi ialah tentang pola asuh orang

Tua, yaitu yang memiliki arti bahwa anak memberikan penafsiran terhadap pola asuh yang diberikan orang tua.

Faktor internal yang dialami individu yaitu dapat berupa kebutuhan psikologis diri, latar belakang yang memiliki kesamaan, pengalaman, kepribadian, sikap dan kepercayaan umum. Faktor internal akan dikelola oleh diri individu sebagai penafsiran akan suatu hal yang berpengaruh terhadap dirinya maupun terhadap lingkungannya. Sedangkan faktor eksternal yang dialami ialah intensitas terhadap stimulus, ukuran stimulus, kontras yang dapat mempercepat ketertarikan, ulangan, gerakan, keakraban, dan sesuatu yang baru. Hal yang diulang dapat membuat ketertarikan, namun bila terlalu sering juga dapat menyebabkan kebosanan. Gerakan merupakan cara untuk menarik perhatian, dengan adanya gerakan seseorang akan lebih tertarik dibanding sesuatu yang diam atau tidak ada pergerakan.

Hasil penelitian bahwa sebagian besar siswi mempersepsikan tipe pola asuh orang tuanya demokratis yaitu sebanyak 59 siswi yaitu $64,1 \%$ dari total responden penelitian. Hal ini menunjukkan orang tua dapat membagi perhatian, komunikasi secara intensif pada anak. orang tua tidak membebaskan atau membiarkan anaknya tanpa memperhatikan perkembangan anaknya, namun orang tua juga tidak memaksakan kehendaknya tanpa berdiskusi memperhatikan minat dan kemampuan anak. Pola asuh demokratis dapat membuat orang tua sebagai pemberi informasi pertama sebelum orang lain terutama pada anak yang tinggal serumah dengan orang tuanya. Keluarga merupakan kelompok 
terkecil yang didalamnya ada interaksi satu sama lain antar anggotanya, dalam pola asuh demokratis orang tua memberikan asuhan yang benar sesuai kebutuhan anak. Remaja cenderung ingin mencari jati diri dan menganggap bahwa dirinya mampu melewati kehidupannya lebih mandiri dibanding ketika masa kanak-kanak.

Pola asuh demokratis dapat membantu remaja untuk menyelesaikan tugasnya secara bijak melalui komunikasi yang baik dan diskusi yang saling menghargai. Remaja putri dapat merasa nyaman dengan pola tersebut karena merasa diayomi dan dapat menjadi semangat untuk memperoleh informasi lebih terkait hal yang disukainya serta bersedia mendengarkan pengalaman yang dimiliki orang tua. Diskusi dilakukan dalam kondisi yang baik sehingga proses tukar pikiran secara efektif dapat terjadi. Orang tua mengantarkan anak untuk menjalankan tugas pekembangannya sesuai dengan usianya.

Analisis tersebut didukung oleh teori Yusuf (2008), yang menjelaskan bahwa pada pola asuh demokratis, orang tua tidak hanya memberikan kebebasan pada anak tetapi juga disertai dengan kontrol. Orang tua dengan pola asuh demokratis memberikan pengertian dasar tentang nilai-nilai yang kuat pada diri anak. Orang tua menyeimbangkan dukungan dengan memberikan kebebasan pada anaknya dalam hal memilih dan melakukan suatu tindakan, serta melalui pendekatan yang hangat. Pemilihan dalam melakukan tindakan menjadi hal penentu terkait langkah yang akan dipilih oleh anak. Remaja akan merasa dihargai ketika diajak untuk berdiskusi. Orang tua dapat memberikan kepercayaan kepada anaknya agar anak memilih dengan konsekuensi yang ada dari pilihan tersebut. Orang tua tentu tidak hanya berhenti sampai memberikan pilihan saja, melainkan juga melakukan pemantauan dan tetap memberikan perhatian kepada remaja. Dukungan dari orang tua sangat diperlukan oleh remaja. Rasa tanggung jawab akan dapat tertanam dan remaja menjadi percaya diri, sehingga remaja akan berusaha semaksimal mungkin. Persepsi tipe pola asuh demokratis sangat membantu dalam hal ini.
Persepsi tentang tipe pola asuh orang tua jika dilihat dari intensitas dan banyak atau sedikit yang diberikan oleh orang tua, dapat diserap dan ditangkap oleh remaja putri. Penangkapan tersebut dapat berupa pengalaman, pedoman yang dianut, motivasi, kepribadian, bahkan mempengaruhi kecerdasan. Remaja putri dapat mengambil pengalaman yang diceritakan orang tua menjadi salah satu bukti bahwa yang telah diceritakan oleh orang tua merupakan salah satu contoh nyata. Pedoman yang dianut dapat membawa remaja putri mengikuti atau mempertimbangkan pedoman orang tuanya. Sedangkan motivasi menjadi dukungan yang besar bagi diri remaja putri, terutama dalam menghadapi perubahan yang terjadi dalam dirinya termasuk petumbuhan dan perkembagan masa pubertas. Orang tua memiliki fungsi peranan yang sangat besar. Menurut Effendy (2004), fungsi pokok orang tua adalah asih, asah dan asuh. Orang tua memberikan kasih sayang, perhatian, rasa aman, kehangatan kepada anggota keluarga sehingga memungkinkan remaja tumbuh kembangnya sesuai dengan usia dan kebutuhannya. Pada fungsi asuh orang tua memberikan pemeliharaan dan perawatan anak agar kesehatan selalu terpelihara terutama pada remaja putri. Remaja identik dengan kegiatan fisik yang banyak dan perlu keseimbangan lingkungan dengan kesehatan dirinya. Adanya hal tersebut diharap dapat menjadikan anak memperoleh kesehatan yang holistik yaitu sehat secara fisik, mental, sosial, dan spiritual. Fungsi asah dari orang tua dapat menjadi memenuhi kebutuhan anak, sehingga siap menjadi manusia dewasa yang mandiri dalam mempersiapkan remaja putri pada masa depannya terutama dengan banyak hal yang akan dipelajari dan akan dihadapinya.

Metode yang dipilih oleh orang tua dalam metode pendidikan anak ialah melalui pola asuh. Tugas perkembangan yang penting pada masa remaja ialah proses bertahap mengembangkan kemampuan yang mandiri agar dapat membuat keputusan yang kompeten. Peran orang tua penting untuk membantu remaja dalam mencapai potensinya secara utuh yaitu cara menjadi manajer yang efektif. 
Manajer yang efektif menjadi upaya yang penting untuk remaja. Selain itu remaja putri dapat menemukan informasi, membuat kontak, membantu menyusun pilihannya dan memberikan bimbingan. Orang tua memberikan pengertian dasar yang kuat sehingga dapat tercipta situasi kepemimpinan. Situasi kepemimpinan yang anggotanya telah diberitahu tujuan kelompok dan anggota diberanikan untuk mendiskusikan serta melakukan kritik pada setiap aktivitas kelompok menurut Kartono (2006). Hasil diskusi dapat menjadi bahan untuk menentukan tujuan selanjutnya dan dapat menjadi evaluasi dari semua pihak. Keterbukaan diperlukan dalam proses memberikan pola asuh agar dapat menjadi teladan yang baik kepada anak, sekaligus mengajak remaja putri untuk lebih terbuka dalam melaksanakan tugas perkembangannya khususnya mengenai pubertas yang dialaminya.

Menurut Soetjiningsih (2004), tipe pola asuh ada tiga yaitu otoriter, permisif, atau demokratis yang berdasarkan pengalaman pribadi orang tua atau pengalaman teman, yang diketahuinya akan menghasilkan hal yang diinginkan untuk anaknya kelak. Pola asuh sebagai metode yang dipilih orang tua untuk mendidik anak yang dipengaruhi oleh pengalaman pribadi orang tua atau orang lain yang diketahui sehingga menghasilkan pembentukan karakter anak.

Hasil penelitian di SMP Negeri 13 Kota Malang tahun 2014 menunjukkan dari 92 siswi, lebih dari setengahnya yakni sebanyak $64,1 \%$ siswi memiliki sikap negatif terhadap perubahan fisik yang terjadi masa pubertas atau menentang hal-hal yang berhubungan dengan perubahan tersebut.

Data yang diperoleh pada remaja putri dalam sikap menghadapi perubahan fisik yang terjadi masa pubertas lebih dari setengahnya yaitu $64,1 \%$ siswi memiliki sikap negatif terhadap perubahan fisik yang terjadi. Apabila anak tinggal bersama orang tua diharapkan orang tua dapat memberikan bimbingan yang baik sehingga dapat terjalin keterbukaan antara orang tua dan anak sehingga dengan informasi komunikatif yang diberikan orang tua dapat membuat anak tidak cenderung bersikap negatif terhadap hal yang terjadi. Jika tinggal serumah maka segala sikap dan perilaku anak dapat langsung diperhatikan orang tua. Orang tua dapat melakukan pemantauan terhadap perkembangan remaja putri. Pemantauan yang dilakukan orang tua tidak hanya melihat atau memperhatikan saja, orang tua dapat menjadi teman yang baik untuk diskusi dan membangun sikap yang baik terhadap suatu hal.

Sikap anak yang baik maka perilaku anak tersebut diprediksi akan baik juga yaitu secara langsung anak akan berusaha menjadi pribadi yang baik, terutama untuk orang yang dianggap penting. Tanggung jawab yang muncul ini membangun sikap pada anak yang akan diaplikasikan melalui tindakannya. Hal ini menunjukkan bahwa meskipun seluruh responden tinggal bersama orang tua, namun tidak banyak mempengaruhi agar bersikap positif dalam menghadapi perubahan fisik yang dialami remaja putri pada masa pubertas. Analisis tersebut didukung pula dengan teori yang menyebutkan interaksi antara anak dengan orang tua merupakan determinan utama sikap anak. Sikap orang tua dan sikap anak cenderung sama atau identik. Namun bila dibandingkan dengan pengaruh teman sebaya, maka pengaruh sikap yang berasal dari orang tua jarang sekali menang (Azwar, 2007).

Jika dilihat dari umur responden penelitian, sebanyak $76,1 \%$ siswi berumur 13 tahun. Penyetaraan umur responden sangat memungkinkan remaja putri yang seumuran lebih banyak kecocokan dan kecenderungan berinteraksi dengan teman sebaya lebih banyak. Seorang remaja dengan remaja yang lain saling berkomunikasi dan bila menemukan kesamaan, mereka akan membangun kelompok atau membangun kepercayaan dalam bermain, bertukar pikiran, dan saling menceritakan pengalaman. Remaja membentuk kelompok dengan adanya kesamaan antar remaja yang satu dengan remaja lainnya. Orang yang dianggap penting dalam pembentukan sikap dapat dimungkinkan tidak hanya terfokus pada orang tua saja, terlebih siswi kelas VII SMP Negeri 13 Kota Malang 100\% responden telah mendapat informasi pertama 
tentang perubahan fisik masa pubertas yang diperoleh dari orang tua, guru, saudara, maupun tenaga kesehatan. Hal tersebut juga didukung dengan pernyataan Azwar (2007), tentang pengaruh lain yang ada seperti halnya pengalaman pribadi yang pernah didapatkan remaja dan membekas pada dirinya, orang yang dianggap penting, pengaruh kebudayaan yang ada dilingkungan remaja putri tersebut, informasi yang didapat dari media massa, serta pengukuran sikap yang dilakukan secara langsung dan tidak langsung. Orang.

Orang yang dianggap penting dapat luas seperti tokoh yang dikagumi, orang yang dipatuhi dan dihormati, serta orang yang dipercaya oleh remaja putri terkait halhal tertentu. Perubahan fisik masa pubertas merupakan hal baru yang dialami remaja putri pada usia remaja awal. Remaja putri membutuhkan orang yang dianggap penting dalam menyikapi perubahan fisik masa pubertas yang sedang dialami. Orang yang dianggap penting memberikan pengaruh yang dapat membentuk sikap, bila yang dianggap penting ialah mampu memberikan informasi yang baik yang berpihak terhadap hal yang sedang dibahas maka dimungkinkan dapat membuat sikap positif. Namun bila orang yang dianggap penting bersikap negatif maka hal yang sama dapat juga ditularkan yaitu sikap negatif terhadap perubahan fisik masa pubertas.

Pubertas merupakan hal yang akan dihadapi oleh remaja. Perlu dukungan dari orang-orang yang ada dilingkungan remaja putri. Sikap menghadapi perubahan fisik masa pubertas dapat menjadi menyenangkan, remaja putri nyaman, dan tidak menjadi beban. Bila perubahan fisik menyebabkan sikap positif maka akan membuat pubertas yang sedang dialami oleh remaja bukan menjadi hal yang mengganggu melainkan yang memang terjadi secara fisiologis pada remaja putri.

Hubungan Persepsi Tipe Pola Asuh Orang Tua dengan Sikap Menghadapi Perubahan Fisik Masa Pubertas di SMP Negeri 13 Kota Malang Tahun 2014.

Hasil utama penelitian ini memperhatikan bahwa berdasarkan hasil uji statistic $\mathrm{x}^{2}$ hitung $<\mathrm{x}^{2}$ tabel $(3,895<$
5,991) dengan demikian Ho diterima yaitu tidak ada hubungan persepsi remaja putrid tentang tipe pola asuh orang tua pada siswi kelas VII di SMP Negeri 13 Kota Malang tahun 2014.

Menurut Azwar (2007), faktor yang mempengaruhi pembentukan sikap yaitu pengalaman pribadi, pengaruh dari orang yang dianggap penting, pengaruh kebudayaan, media massa, lembaga pendidikan dan lembaga agama, serta pengukuran sikap. Dalam penelitian ini yang dapat dikendalikan oleh peneliti adalah lembaga pendidikan karena responden diambil dari sekolah atau lembaga pendidikan yang sama dengan tingkat pendidikan yang sama yaitu pada siswi kelas VII.

Pengaruh orang yang dianggap penting merupakan salah satu komponen sosial yang dapat mempengaruhi sikap seseorang. Salah satu orang yang dapat dikategorikan menjadi orang yang dianggap penting adalah orang tua (Azwar, 2007), bila dikaitkan dengan hasil penelitian didapat bahwa seluruh responden $100 \%$ tinggal serumah dengan orang tuannya.

Damaiyanti (2008) menyebutkan bahwa remaja merupakan masa transisi dari akhir masa kanak-kanak menuju masa dewasa, didukung dengan pernyataan Sarwono (2011) tentang remaja awal yaitu pada usia 12-15 tahun yang pada tahap ini masih heran akan perubahan yang terjadi pada tubuhnya sendiri dan dorongan yang menyertai perubahan tersebut. Terkait hasil penelitian 92 siswi telah mempersepsikan tipe pola asuh orang tuanya. Persepsi tipe pola asuh terbanyak ialah demokratis sejumlah $64,1 \%$ siswi, sedangkan persepsi tipe pola asuh yang tersedikit ialah otoriter sejumlah $15,2 \%$. Dalam hal ini orang tua sebagai lingkungan sosial pertama remaja diharapkan dapat menerapkan pola asuh yang mengutamakan adanya interaksi dialog terbuka tentang perubahan fisik masa pubertas yang dapat disampaikan melalui pendekatan yang hangat sehingga remaja memiliki sikap yang benar tentang perubahan fisik yang terjadi pada masa pubertas, mengingat karakteristik remaja dengan emosi yang meluap-luap dan kebutuhan akan kasih sayang. Oleh karena 
itu, pola asuh orang tua sangat penting untung membentuk sikap remaja tentang perubahan fisik masa pubertas.

Pada hasil penelitian dari 92 siswi bahwa tipe pola asuh orang tua yang paling banyak dipersepsikan oleh responden adalah demokratis $64,1 \%$ yang sebagian besar $71,2 \%$ memiliki sikap negatif terhadap perubahan fisik masa pubertas. Padahal orang tua dengan pola asuh demokratis memprioritaskan kepentingan anak dan tanpa ragu dalam mengendalikan. Orang tua selalu bersikap rasional dalam suatu pemikiran. Orang tua juga bersikap mendukung kemampuan anak, tidak menuntut anak untuk menjadi lebih melampaui kemampuan anak. Menurut Yusuf (2008), orang tua menyeimbangkan dukungan dengan memberikan kebebasan kepada anak-anaknya dalam hal memilih dan melakukan suatu tindakan, dan pendekatannya kepada anak bersikap hangat. Begitu pula yang dibutuhkan oleh remaja, seperti yang dibahas Sntrock (2007), bahwa untuk membantu remaja mencapai potensi seutuhnya, salah satu peran orang tua yang penting adalah menjadi manajer yang efektif, yang menemukan informasi, membuat kontak membantu menyusun pilihan-pilihannya dan memberikan bimbingan.

Berdasarkan hasil penelitian didapat sebanyak $64,1 \%$ responden mempersepsikan tipe pola asuh orang tuanya demokratis yang kecenderungan orang tua tipe demokratis dapat membentuk karakteristik anak yang dapat mengontrol dirinya sendiri. Namun dengan perkembangan jaman yang maju ini, tidak mustahil remaja terjebak dalam lingkungan yang apabila seorang pribadi yang mempunyai pengalaman yang buruk tentang perubahan fisik yang meninggalkan kesan kuat sehingga membuat emosi akan pengalaman menjadi lebih mendalam, hal tersebut akan menjadi pengalaman yang buruk bahkan menjadi suatu hal yang tidak perlu untuk didiskusikan. Ini diakibatkan emosi remaja yang masih labil, remaja masih belum mampu menguasai dan belum dapat memfungsikan secara maksimal fungsi fisik maupun psikisnya.

Analisis tersebut didukung dengan teori yang menjelaskan bahwa pengalaman pribadi, hal yang diceritakan orang, dan kebutuhan emosi diri sendiri merupakan determinan utama dalam terbentuknya kepercayaan. Pengalaman pribadi yang digeneralisasikan tersebut akan membentuk steriotipe. Apabila steriotipe tersebut telah berakar sejak lama, maka orang kemudian akan mempunyai sikap yang didasarkan pada objek sikap tertentu. Sikap yang didasari oleh steriotipe (kata ini diganti anggapan negatif) semacam ini biasanya sangat sulit untuk menerima perubahan (Azwar, 2007). Sikap yang dihasilkan dari pengalaman pribadi yang tidak menyenangkan akan membuat pribadi seseorang menjadi tidak senang atau menghindari hal berkaitan dengan pengalaman tersebut. Sedangkan pengalaman pribadi yang menyenangkan dan menarik dapat membuat seseorang bersikap positif terhadap hal yang berhubungan dengan pengalaman tersebut. Pengalaman yang berkesan dapat menjadi cermin steriotip dari hal yang serupa.

Pertumbuhan yang terjadi pada tubuh remaja putri saat pubertas berupa tumbuhnya ciri-ciri seks sekunder dan menarch. Perubahan seks sekunder yang terjadi ialah pada pinggul, payudara, rambut, kulit, otot, dan suara. Pinggul membesar dan bulat akibat pembesaran tulang panggul serta perkembangan lemak bawah kulit. Payudara dan papila mamae semakin menonjol dengan berkembangnya kelenjar susu. Perubahan yang lain yang terjadi ialah tumbuhnya rambut pada ketiak, kemaluan, lengan, kaki, dan wajah. Pada kulit juga terjadi perubahan menjadi lebih kasar, lebih tebal, agak pucat dan lubang poripori bertambah besar. Perubahan pada otot ialah otot semakin kuat dan besar sehingga memberikan bentuk pada bahu, lengan dan tungkai kaki. Sedangkan pada suara, remaja putri akan mengalami perubahan suara dari suara kanak-kanak menjadi lebih merdu dan melengking.

Faktor yang selanjutnya juga membentuk sikap adalah kebudayaan. Kebudayaan sangat mempengaruhi orang yang berada di lingkungan kebudayaan tersebut. Jika seorang remaja berada dalam budaya lingkungan sekitar yang masih menganggap bahwa membicarakan bahkan untuk mencari tahu tentang perubahan 
fisik masa pubertas adalah suatu tindakan yang tabu dan memalukan. Budaya yang seperti itu memang mebuat remaja putri terbiasa dengan batasan-batasan yang telah dipupuk dan menjadi suatu kepercayaan pada dirinya. Jika hal tersebut terjadi dapat membuat remaja cenderung bersikap negatif. Mereka malu jika disinggung tentang perubahan fisik pubertas yang terjadi. Ketika hal tersebut terjadi, akhirnya berdampak negatif terhadap perkembangan yang dipilih remaja putri. Namun menurut Yusuf (2008), fase remaja merupakan segmen perkembangan individu yang sangat penting, diawali dengan matangnya organ-organ fisik (seksual) hingga mampu bereproduksi. Seperti yang didapatkan dari penelitian, menunjukkan lebih dari setengah responden penelitian bersikap negatif dalam menghadapi perubahan fisik masa pubertas, yaitu sebanyak $64,1 \%$ siswi. Maka dari itu pada fase ini pengenalan serta pemahaman yang bijak tentang perubahan fisik masa pubertas sangatlah diperlukan oleh remaja. Pengenalan tentang perubahan fisik masa pubertas sebagai upaya agar responden dapat memahami dan menelaah bahwa perubahan yang terjadi merupakan hal yang biasa terjadi dan tidak perlu untuk dikhawatirkan.

Kebutuhan akan informasi sebagai cara membantu remaja putri untuk dapat memahami pertumbuhan fisik masa pubertas membuat remaja putri mencari tahu melalui berbagai sumber. Pada penelitian remaja putri di SMP Negeri 13 Kota Malang 100\% responden telah mendapat informasi tentang perubahan fisik masa pubertas. Hanya sebagian kecil yaitu 4,4\% diantaranya mendapat informasi oleh tenaga kesehatan. Ini disebabkan interaksi remaja dengan tenaga kesehatan masih jarang. Bila diketahui peran tenaga kesehatan sangatlah penting karena tenaga kesehatan dapat memberikan informasi secara menyeluruh terutama kebutuhan akan memaknai dan mengerti tentang perubahan fisik yang terjadi pada masa pubertas. Tenaga kesehatan dapat melakukan pendidikan kesehatan reproduksi pada tingkat sekolah melalui pendidikan kesehatan reproduksi yang bekerja sama dengan guru pengajar kelas serta pada kegiatan ekstrakulikuler.
Tenaga kesehatan juga dapat melakukan pendidikan kesehatan pada organisasi remaja salah satunya melalui Pusat Informasi dan Konseling Reproduksi Remaja (PIKKRR). Kegiatan yang dilakukan selain memberikan pendidikan kesehatan dapat juga dilakukan dengan melatih kader sebaya. Tenaga kesehatan dapat menghimpun serta memberikan pelatihan kepada remaja yang dapat dijadikan sebagai kader dalam memberikan informasi dan membangun jejaring agar remaja secara mandiri dapat membangun sikap positif terutama terhadap perubahan fisik yang terjadi masa pubertas yaitu melalui konten informasi yang benar dan tepat.

Berbagai media dapat membantu remaja dalam memperoleh informasi. Media massa sebagai salah satu sumber yang dapat cepat untuk diakses oleh remaja. Penyaringan informasi perlu dilakukan karena bila tidak arif juga menyebabkan remaja menjadi salah tangkap tentang informasi yang diperoleh. Akses tentang hal negatif yang berhubungan dengan seksualitas dapat dengan mudah diperoleh yang dapat merusak moral remaja. Menurut Notoatmodjo (2005), media massa membawa pesan-pesan berisi sugesti yang dapat mengarahkan opini yaitu adanya informasi baru bagi terbentuknya sikap terhadap hal tersebut. Media massa diharapkan dapat membantu remaja putri dalam memberikan informasi yang dibutuhkan sehingga informasi tersebut dapat bermanfaat dan dapat digunakan sebagai penambah wawasan. Rasa ingin tahu yang tinggi pada diri remaja dapat memotifasi remaja untuk mampu mencari dan mendapatkan informasi yang baik. Media massa dapat dijadikan tempat untuk belajar dan menggali informasi terutama yang berkaitan dengan kesehatan reproduksi mencakup informasi yang dibutuhkan seputar reproduksi remaja. Kesehatan reproduksi remaja perlu diketahui terutama bagi remaja awal. Bila media massa dapat memberikan informasi yang tepat dan dapat dipahami oleh remaja putri, maka tidak memberikan pengukuran sikap negatif terhadap perubahan fisik pada masa pubertas. Remaja putri dapat salah dalam bersikap, maka dari itu diperlukan adanya informasi yang dapat digunakan sebagai 
referensi memahami perubahan fisik yang dialami.

Pengaruh kebudayaan juga mengambil peranan penting dalam pembentukan sikap. Suatu hal mendapat penilaian di masyarakat sesuai dengan kebiasaan dan norma yang berkembang di lingkungan masyarakat itu sendiri. Bila kebudayaan yang ada dilingkungan tersebut merupakan hal yang positif maka dapat membuat sikap remaja menjadi positif pula dan sebaliknya bagi hal yang dianggap negatif atau bertentangan dengan budaya akan membuat sikap menjadi negatif. Penilaian terhadap suatu hal tersebut dapat mempengaruhi sikap seseorang yang terlibat atau dilingkungan, seperti yang diungkapkan Azwar (2007) bahwa sikap sosial terbentuk dari adanya interaksi sosial yang dialami oleh individu.

Lembaga pendidikan dan lembaga agama menurut Notoatmodjo (2005) menanamkan dasar pengertian dan moral dalam diri individu sehingga dapat mempengaruhi pembentukan sikap individu. Individu mendapat pelajaran dasar sebagai pondasi menjalani kehidupan. Lembaga pendidikan menjadi suatu tempat yang tepat dalam pembelajaran. Pengajar yang kompeten dan penjelasan yang mudah dipahami membuat murid atau anak didik menjadi tertarik untuk belajar. Ketertarikan akan ilmu yang diperoleh menjadi peluang agar segala bentuk yang diajarkan dapat diingat dan diterapkan dalam keseharian. Pendidikan baik formal maupun informal memberi sumbangsih terbesar mengajarkan pengetahuan dan pengalaman terhadap suatu hal yang sedang dipelajari. Pengajar dapat menjadi salah satu sumber pemberi informasi yang membentuk sepak positif atau negatif terhadap sesuatu. Proses transfer ilmu juga dilakukan dilingkungan lembaga agama. Lembaga pendidikan tidak lepas juga dari peran lembaga agama. Lembaga agama menanamkan nilai-nilai keagamaan tentang kehidupan sebagai pemeluk agama dan ciptaan lain tuhan. Budi pekerti yang luhur juga dapat dibiasakan dan menjadi kearifan diri. Lembaga agama mengajarkan untut selalu bersikap positif terhadap kondisi yang sedang dihadapi. Pada hal ini menjadikan pemeluk agama dapat saling menghormati dan menghargai dengan perbedaan yang dimiliki masingmasing. Sikap yang timbul dari kejadian tertentu membawa manusia akan mengarah pada sikap positif atau negatif. Agama menjadi kontrol dalam bersikap karena dengan berpegang pada agama manusia menjalani hidup. Lembaga pendidikan dan lembaga agama dapat dijadikan media untuk menyalurkan informasi khususnya mengenai perubahan fisik yang terjadi masa pubertas pada remaja putri. Remaja putri akan mendapatkan banyak informasi dari banyak pihak dan pubertas yang dialami menjadi hal yang nyaman dan remaja bersikap positif menghadapinya. Remaja putri dapat membawa dampak positif bagi lingkungannya.

\section{SIMPULAN}

Berdasarkan hasil penelitian yang telah dilakukan di SMP Negeri 13 Kota Malang dengan responden siswi kelas VII, dapat ditarik beberapa kesimpulan yakni sebagai berikut: Sebagian besar remaja putri kelas VII di SMP Negeri 13 Kota Malang mempersepsikan tipe pola asuh orang tuanya demokratis. Lebih dari setengah remaja putri di SMP Negeri 13 Kota Malang memiliki sikap negatif terhadap perubahan fisik masa pubertas. Tidak ada hubungan persepsi remaja putri tentang tipe pola asuh orang tua dengan sikap menghadapi perubahan fisik masa pubertas. Remaja putri yang mempersepsikan pola asuh orang tuanya demokratis memiliki sikap negatif terhadap perubahan fisik masa pubertas.

\section{SARAN}

Setelah penelitian Hubungan Persepsi Tipe Pola Asuh Terhadap Sikap Menghadapi Perubahan Fisik Pubertas dilakukan, penulis menyarankan bagi peneliti selanjutnya yang tertarik untuk penelitian sejenis dapat memperhatikan faktor-faktor yang dapat mempengaruhi persepsi remaja putri tentang tipe pola asuh dan sikap menghadapi perubahan fisik masa pubertas dengan menggunakan sumber penelitian yang lebih luas.

Pihak SMP Negeri 13 Kota Malang hendaknya mengembangkan penjelasan 
program sekolah yang bertujuan untuk meningkatkan pemahaman siswi tentang kesehatan reproduksi melalui kerjasama dengan tenaga kesehatan atau institusi kesehatan sehingga diinformasi yang dibutuhkan oleh remaja putri dapat diperoleh. Contoh dari kegiatan yang dapat dilakukan ialah melalui gerakan program parenting class bagi orang tua tentang seks edukasi. Orang tua dapat menjadi orang yang dapat mengedukasi remaja putri sehingga pembentukan sikap positif terhadap perubahan fisik masa pubertas dapat menjadi hal yang nyaman dan remaja putri mampu menjalani masa pubertasnya secara arif dan bijaksana.

Petugas kesehatan hendaknya memberikan pemahaman kepada masyarakat, baik orang tua maupun remaja melalui program kesehatan reproduksi remaja. Promosi kesehatan dan pendidikan kesehatan pada Posyandu remaja sebagai contoh bahwa pola asuh diharapkan mampu memberikan gambaran kemungkinan perilaku yang timbul dari orang yang bersangkutan dan dapat mengurangi kegagalan dalam memaknai tahap perkembangan remaja khususnya remaja putri.

\section{DAFTAR PUSTAKA}

Azwar, Saiffudin. 2007. Sikap Manusia, Teori, dan Pengukurannya. Yogyakarta: Pustaka Pelajar.

Damaiyanti, Mukhripah, 2008. Komunikasi Terapeutik dalam Praktik Keperawatan. Bandung: Refika Aditama

Effendy, N.,2004, Dasar-dasar Keperawatan Kesehatan Masyarakat. Jakarta: Renika Cipta.

Notoatmodjo, Soekidjo, 2005. Metodologi Penelitian Kesehatan. Jakarta: Rineka Cipta.

Rochmania, Siti N.I., 2014. "Gambaran Pengetahuan dan Sikap Remaja Putri dalam Menghadapi Perubahan Fisik Saat Pubertas di Pondok Pesatren AlBaqiyatussholihat" Skripsi. Fakultas Kedokteran dan Ilmu Kesehatan. Universitas Islam Negeri Syarif Hidayatullah, Jakarta

Santrock, John W. 2007. Remaja Jilid 1 Edisi 11. Jakarta: Erlangga.

Sarwono, Sarlito W., 2011. Psikologi Remaja. Jakarta: Rajawali Pers.

Soetjiningsih. 2004. Buku Ajar Tumbuh Kembang Remaja dan Permasalahannya. Jakarta: KDT.

Yusuf. 2008. Psikologi Perkembangan Anak dan Remaja. Bandung: PT Remaja Rosdakarya. 